\title{
Exogenous surfactant treatment for the adult respiratory distress syndrome? A historical perspective
}

Von Neergaard's classic work of $1929^{1}$ describing how the lungs were more difficult to inflate with air than with fluid was commemorated recently at a meeting celebrating 60 years of surfactant research. ${ }^{2}$ The first 30 years of endeavour have been eloquently described by Comroe. . $^{3-5}$ In the last 30 years progress has been phenomenal, since Clements first measured the surface tension of lung fluid extracts ${ }^{6}$ and identified dipalmitoylphosphatidylcholine as the main surface active component ${ }^{7}$ and since Avery and Mead showed that the lungs of infants with hyaline membrane disease had a much higher surface tension than normal lungs. ${ }^{8}$ Understanding of the chemistry, physics, physiology, and pathophysiology of the pulmonary surfactant system has accelerated, Enhorning and Robertson providing the catalyst by showing the effectiveness of surfactant replacement treatment in premature animals. ${ }^{9}$ The structure and function of pulmonary surfactant have been elucidated and a wide range of surfactant preparations for therapeutic use is now available (table 1). Can this new knowledge be applied to improve the treatment of the adult respiratory distress syndrome?

In 1967 Ashbaugh et al $^{10}$ described the development of respiratory failure in 12 patients with dyspnoea, arterial hypoxaemia unresponsive to increasing inspired oxygen concentrations, reduced lung compliance, and diffuse infiltrates on the chest radiograph. Postmortem examination of the lungs of seven patients showed them to be haemorrhagic, with excess fluid in both the alveolar and interstitial spaces. Hyaline membranes formed from cell debris and protein were also seen. The clinical and histological appearances were very similar to those of the respiratory distress syndrome in babies and the name adult respiratory distress syndrome (ARDS) was proposed by Petty and Ashbaugh in 1971. ${ }^{11}$

In the adult respiratory distress syndrome the exact sequence of changes is not understood but complement activation is thought to lead to leucocyte aggregation. Oxygen derived free radicals and proteases are released, causing damage to the alveolar-capillary membrane and making it more permeable. Platelet aggregation leads to mediator release, with activation of the coagulation and fibrinolytic systems causing further severe damage to the pulmonary vasculature. Other mediators, such as tumour necrosis factor, and cytokines, such as the interleukins, are also important in the cascade leading to the syndrome. ${ }^{12}$

Surfactant is damaged in patients with the adult respiratory distress syndrome. Petty et al showed that abnormally aggregated and inactive surfactant occurred in bronchoalveolar lavage fluid from patients with the condition. ${ }^{13}$ The mechanisms leading to this inhibition and inactivation of surfactant have been reviewed recently. ${ }^{14}$ The functional impairment of surfactant is exacerbated by a quantitative deficiency of surfactant due to damage to type 2 pneumocytes early in the course of the adult respiratory distress syndrome.

It is salutary to note that the mortality in the series of Ashbaugh et al $^{10}$ series is similar to the current overall mortality for the adult respiratory distress syndrome of 50$70^{\circ}{ }_{0}{ }^{12}$ Of those who survive, some have dyspnoea, wheezing, or recurrent respiratory infections. On formal testing, up to $40^{\circ}{ }_{0}$ have impairment of pulmonary function. Upper airway problems may occur, particularly in children, as a result of prolonged endotracheal intubation. ${ }^{15}$ The adult respiratory distress syndrome still carries a very high morbidity and mortality and any new therapeutic avenue is worth exploring.

\section{Composition, production, and recycling of endogenous pulmonary surfactant}

Phospholipids make up $85 \%$ of natural pulmonary surfactant, with dipalmitoylphosphatidylcholine as the main surface active component (table 2). Some of the proteins are specific to surfactant (surface proteins $A, B$, and $C$ (SP$A, S P-B$, and SP-C)) and have been the subject of intense study recently. SP-A is a glycoprotein of molecular weight 26-36 kilodaltons. Eighteen monomers associate to form six triple helices, a structure that is remarkably similar to that of Clq, a subunit of the first component of the

Table 1 Surfactant preparations

\begin{tabular}{|c|c|c|c|}
\hline & Source & Components & Examples \\
\hline Natural surfactant & $\begin{array}{l}\text { Human or animal alveolar lavage } \\
\text { fluid, amniotic fluid }\end{array}$ & $\begin{array}{l}\text { Phospholipids, neutral lipids, } \\
\text { proteins }\end{array}$ & Helsinki, San Diego \\
\hline Modified natural surfactant & $\begin{array}{l}\text { Human or animal alveolar lavage } \\
\text { fluid, lung extract }\end{array}$ & $\begin{array}{l}\text { Phospholipids, neutral lipids, } \\
\text { proteins }\end{array}$ & Surfactant-TA, Curosurf, Servanta \\
\hline Artificial surfactant & Synthesis in vitro & $\mathrm{DPPC} \pm$ an alcohol & $\begin{array}{l}\text { Exosurf (Wellcome), ALEC } \\
\text { (Britannia) }\end{array}$ \\
\hline Synthetic natural surfactant & Synthesis in vitro & $\begin{array}{l}\text { Phospholipids, neutral lipids, } \\
\text { surfactant specific } \\
\text { apoproteins, (SP-A, SP-B, } \\
\text { SP-C) }\end{array}$ & California Biotechnology \\
\hline
\end{tabular}


Table 2 Composition of natural pulmonary surfactant

\begin{tabular}{|c|c|}
\hline Component & Functions \\
\hline $\begin{array}{l}\text { Phospholipids } 85 \% \text {, } \\
\text { mainly DPPC }\end{array}$ & Main surface active component \\
\hline \multicolumn{2}{|l|}{ Neutral lipids $5 \%$} \\
\hline \multirow[t]{2}{*}{$\begin{array}{l}\text { Proteins } 10 \% \\
\text { SP-A }\end{array}$} & Enhances phagocytosis \\
\hline & $\begin{array}{l}\text { Regulates surfactant secretion and } \\
\text { reuptake } \\
\text { Organises the structure of alveolar } \\
\text { surfactant }\end{array}$ \\
\hline SP-B & $\begin{array}{l}\text { Enhances adsorption/spreading at air/ } \\
\text { liquid interface }\end{array}$ \\
\hline SP-C & $\begin{array}{l}\text { Purifies the monolayer } \\
\text { Breaks bilayers of lipid }\end{array}$ \\
\hline & $\begin{array}{l}\text { Accelerates adsorption and spreading at } \\
\text { air-liquid interface }\end{array}$ \\
\hline
\end{tabular}

complement pathway. This raises the intriguing possibility of a role for surfactant in the immune responses of the lung.

Receptors for SP-A are to be found on the surface of type 2 pneumocytes and SP-A regulates surfactant secretion and reuptake by these cells ${ }^{16}$ (fig 1). SP-A enhances phagocytosis by binding to surface receptors on alveolar macrophages.

SP-A also has a role in organising the structure of the surfactant quantum packages exocytosed by type 2 cells from their storage vesicles, the lamellar bodies (fig 2). SPA, with SP-B and calcium ions, promotes the formation of a curious lattice structure known as tubular myelin, which is an intermediate form of surfactant, en route to the airliquid interface. ${ }^{17}$

The gene encoding SP-A has been identified on chromosome 10 and has been sequenced ${ }^{18}$ and translated in vitro. ${ }^{19}$ It is expressed only by type 2 cells. The genes for SP-B and SP-C are also known and are subject to cell specific expression. SP-B and SP-C are low molecular

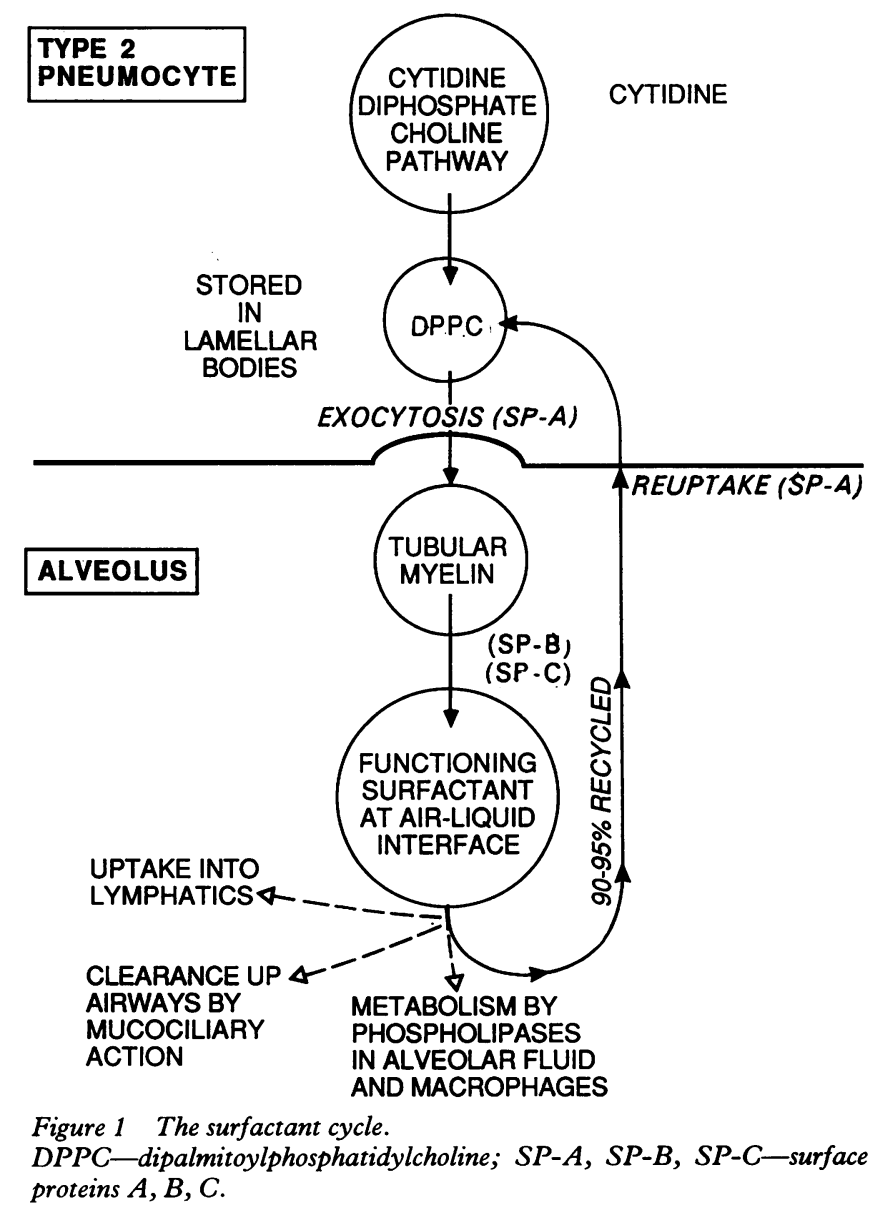

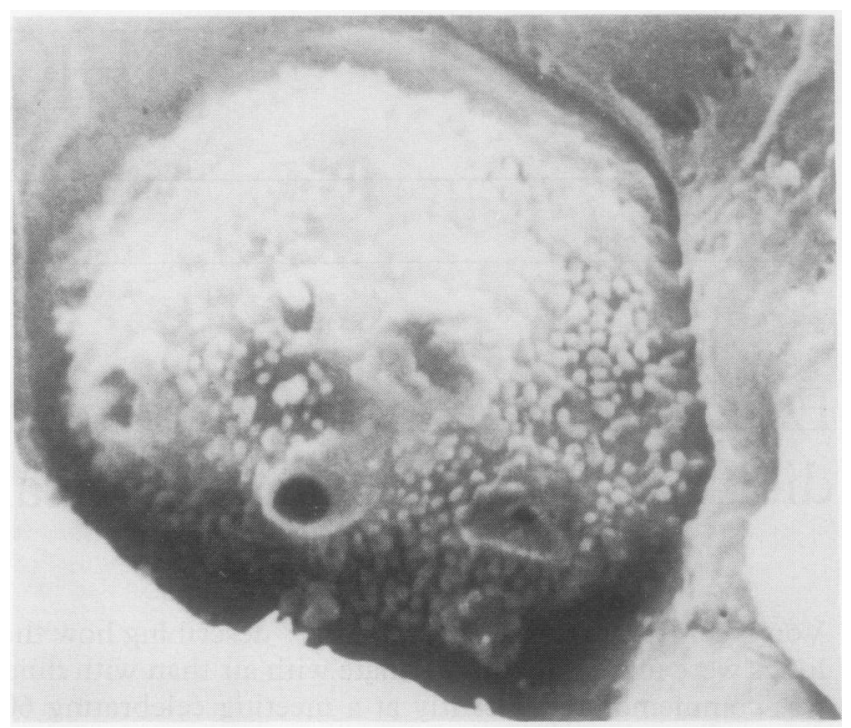

Figure 2 Type 2 pneumocyte extruding a package of surfactant by exocytosis. Original scanning electron micrograph provided personally by Dr Charles Kuhn and reproduced with his permission.

weight, hydrophobic proteins. SP-C is a bilayer breaker that accelerates the adsorption and spreading of surfactant phospholipid at the air-liquid interface. SP-B also enhances adsorption and spreading but, in addition, promotes the squeezing out of "impurities" from the lipid monolayer during expiration so that this layer becomes closer to pure dipalmitoylphosphatidylcholine. The functions of the three surfactant specific apoproteins thus complement each other and show synergism in terms of surface activity, provided that calcium ions are present in adequate amounts. ${ }^{20}$

Synthesis of surfactant lipids occurs in the cytidine diphosphate choline pathway of type 2 pneumocytes (fig 1 ). The surfactant is packaged and stored as lipid bilayers in lamellar bodies, which are exocytosed into the alveolar lumen. Ninety to ninety five per cent of secreted alveolar surfactant is recycled, reprocessed, refined, and repackaged for resecretion. Exogenously administered surfactant can provide substrate for the patient's own endogenous cycle by being taken up by the type 2 cells and incorporated into the surfactant pool. ${ }^{21}$

\section{Consequences of the physiological effects of surfactant}

It is clear from the laboratory studies and the clinical trials in neonates that surfactant administration produces several effects that could prove to be of benefit to the patient with the adult respiratory distress syndrome (table 3 ).

\section{EFFECTS ON LUNG MECHANICS}

By lowering surface tension surfactant allows collapsed alveoli to open at lower inspiratory pressures and these alveoli are protected against collapse during expiration. Thus exogenous surfactant would allow closed lung units to be recruited and functional residual capacity would increase. As lung compliance is increased, the airway and alveolar opening pressure is decreased and the work of breathing is reduced. Ventilation-perfusion matching is improved and intrapulmonary right to left shunting is reduced. Gaseous exchange is improved by a combination of these effects and by the enhancement of alveolar fluid clearance caused by the water repellent properties of surfactant. ${ }^{223}$

The consequence of these improvements in pulmonary 
Table 3 Potentially beneficial effects of exogenous surfactant treatment in the adult respiratory distress syndrome

Produces stable low surface tension, which prevents alveolar collapse Recruits closed lung units

Increases lung compliance

Decreases work of breathing

Decreases airway and alveolar opening pressure

Improves gaseous exchange

Reduces ventilator related lung damage

Reduces pulmonary oxygen toxicity

Enhances alveolar fluid clearance

Has anti-stick properties

Enhances foreign particle clearance

Protects cell surfaces

Stimulates phagocytosis of bacteria and viruses

function may be to allow the patient to be managed with a lesser degree of ventilatory support. The inspired oxygen concentration, peak inspiratory pressure, level of positive end expiratory pressure and duration of ventilation could all be decreased. Cardiac output and oxygen delivery would be better maintained and barotrauma to the lung parenchyma would be minimised by the avoidance of high mean intrathoracic and airway pressures. Reducing the damage to alveolar epithelial cells lessens the tendency to leakage into the alveolar lumen of serum proteins and red cell debris, which are potent inhibitors of surfactant and contribute to the formation of hyaline membranes in neonatal and adult respiratory distress syndrome. ${ }^{23-26}$

\section{REDUCTION OF OXYGEN TOXICITY}

A substantial reduction in inspired oxygen concentration can be achieved after surfactant treatment in neonates. ${ }^{21}$ This is likely to be important in the adult respiratory distress syndrome, particularly where the underlying cause increases oxygen derived free radical production, as in paraquat poisoning, cancer chemotherapy, and radiotherapy. These reactive radicals impair the activity of phospholipid biosynthetic enzymes, with decreased surfactant synthesis resulting in decreased alveolar surfactant concentrations. ${ }^{27} 28$ Hyperoxia for prolonged periods and the reperfusion phase after an ischaemic insult both generate free radicals. As type 2 pneumocytes contain the enzyme xanthine oxidase they are particularly at risk from free radical damage. ${ }^{29}$ This enzyme is an important catalyst of reactions leading to the production of oxygen derived free radicals. In a recent study to determine whether surfactant has any free radical scavenging activity, the catalase and superoxide dismutase antioxidant activities of various surfactant preparations were measured. Natural lung surfactant had considerable activity but surfactant extracts had none. ${ }^{31}$ Holm suggested that because exogenously administered natural surfactant is taken up into type 2 pneumocytes this could reduce the steady state intracellular and extracellular concentrations of reactive oxygen species. ${ }^{14}$ Another study, however, found that the antioxidant activity of various surfactant preparations was insufficient to provide clinically useful protection against pulmonary oxygen injury. ${ }^{32}$ Any reduction in alveolar partial pressures of oxygen that is achieved as a result of exogenous surfactant treatment is likely to be beneficial in limiting free radical induced pulmonary damage. ${ }^{142833}$

\section{ANTIBACTERIAL AND ANTIVIRAL ACTIVITY}

Surfactant is now known to have antibacterial and antiviral activity by stimulating alveolar macrophage phagocytosis. ${ }^{34} 35$ SP-A enhances phagocytosis by binding to surface receptors on alveolar macrophages. The similarity of SP-A to the Clq subunit of the complement system has already been noted.

\section{ANTI-INFLAMMATORY ACTIVITY}

The lung has an important metabolic role in deactivating inflammatory mediators, and surfactant may play a part in this process. This possibility is supported by the recent finding that surfactant counters the effects of platelet derived inflammatory mediators and angiotensin II. ${ }^{36}$

\section{WATER REPELLENT EFFECTS}

Surfactant has water repellent properties, which may aid the clearance of alveolar and interstitial fluid in conditions associated with pulmonary oedema, such as the adult respiratory distress syndrome. Hills has proposed that the alveoli are normally dry and any fluid is repelled into corner menisci, which then act as pumps pushing fluid out into the interstitial spaces. In this model surfactant is adsorbed on to the alveolar epithelial cells, producing an anti-stick, hydrophobic surface. ${ }^{3738}$

\section{CYTOPROTECTIVE EFFECTS}

In the adult respiratory distress syndrome the alveoli are flooded with proteinaceous fluid that inhibits and denatures pulmonary surfactant. If enough surfactant is delivered to the alveoli, the surfactant inhibiting effect of proteins in the alveoli can be overcome. Surfactant treatment has been shown to reduce the protein leak as measured by the clearance of ${ }^{99 \mathrm{~m}}$ Tc DPTA, a sensitive indicator of lung permeability. ${ }^{39-41}$ This may be due to the ability of surfactant to protect alveolar cell surfaces from the agents that damage the alveolar-capillary membrane. ${ }^{42}$

\section{Studies of exogenous surfactant treatment} NEONATAL RESPIRATORY DISTRESS SYNDROME

The current position of surfactant treatment in neonatology has recently been reviewed. ${ }^{21}$ There seems to be great reluctance to undertake comparative trials of different surfactant preparations because of the large numbers of patients and the high costs. Large parallel, collaborative trials using the same protocol are, however, being organised to evaluate the synthetic surfactant Exosurf (Wellcome) and the modified natural surfactant Cursosurf (see table 1 for different forms of surfactant).

From the many trials so far carried out, with their widely varying protocols, a consensus has emerged (see ref 23) that surfactant treatment for neonatal respiratory distress syndrome reduces mortality and morbidity due to pneumothorax, pulmonary interstitial emphysema, bronchopulmonary dysplasia, and intraventricular haemorrhage. Synthetic surfactants are beneficial when given prophylactically, and natural surfactants may also be effective in rescuing babies with established respiratory distress syndrome. Prophylaxis with either type of surfactant reduced mortality by half and prophylaxis with natural surfactant reduced pneumothorax by half and doubled the rate of survival free of bronchopulmonary dysplasia. In rescue studies natural surfactant reduced mortality by $40 \%$, pneumothorax by $70 \%$, intraventricular haemorrhage by $25 \%$, and bronchopulmonary dysplasia by $35 \%$ and increased survival free of bronchopulmonary dysplasia by $40 \%$. Patency of the ductus arteriosus was increased by $30 \%$ and was treated by indomethacin or surgical ligation. No antigenic reactions were seen, despite the protein content of the natural surfactant preparations, and long term follow up studies have shown no adverse effects. ${ }^{23}$

The dose of surfactant administered in these studies has varied from 50 to $200 \mathrm{mg}$ of surfactant phospholipid/kg in a volume of $2-4 \mathrm{ml}$. This is roughly the size of the alveolar surfactant pool. The surfactant suspension is instilled via a fine bore feeding tube into the trachea. The baby is positioned alternately with the right and left lungs depen- 
dent and manual ventilation is carried out to encourage even distribution of the surfactant material.

The response is usually rapid, with an immediate rise in arterial oxygen tension and a fall in oxygen requirements from around $80 \%$ to $50 \%$ or less within 30 minutes. Any decrease in arterial carbon dioxide tensions lags behind the improvement in oxygenation. The reasons for this are not clear. Reductions in ventilatory settings also occur more slowly; typically the ventilatory index (that is, the product of peak inspiratory pressure and frequency) will fall by $35 \%$ over four hours. Pulmonary blood flow remains the same during this time. An immediate increase in pulmonary compliance has been measured in infants breathing spontaneously, and this was thought to be due to a reduction in atelectasis and an increase in functional residual capacity.

In some babies these improvements in pulmonary function are sustained after a single dose of surfactant. In others multiple doses are required to maintain the improvement. ${ }^{17}$ The optimal dosage regimen has yet to be devised and the planned collaborative studies are designed to answer this question.

\section{ADULT RESPIRATORY DISTRESS SYNDROME}

In his original report of the adult respiratory distress syndrome, Ashbaugh ${ }^{10}$ noted high minimum surface tension values of greater than 20 dyne $/ \mathrm{cm}$ in lung extracts from two patients, a functional abnormality confirmed in a later study. ${ }^{1143}$ Phospholipid concentrations in bronchoalveolar lavage samples from patients with the adult respiratory distress syndrome were normal or even high but the phospholipid composition was abnormal, with low levels of dipalmitoylphosphatidylcholine and phosphatidylglycerol. ${ }^{43}$

\section{Animal studies of the adult respiratory distress syndrome} The response of the lung in the varied animal models of the adult respiratory distress syndrome reflects the variations in the severity and the time course of the clinical condition with atelectasis, decreased compliance, and permeability pulmonary oedema. ${ }^{14}$ Quantitative surfactant deficiency due either to impaired phospholipid metabolism or to destruction of type 2 pneumocytes has been documented. Bronchoalveolar lavage samples show high surface tension values resulting from inhibition and inactivation of surfactant by serum proteins and membrane lipids in the alveoli. The degree of inhibition depends on the surfactant concentration. A quantitative deficiency of surfactant exacerbates any functional deficiency, and by increasing the surfactant concentration inhibition by alveolar protein can be overcome. ${ }^{24-2644}$ Some types of surfactant used in treatment may be more resistant to protein inhibition than others. ${ }^{14}$ Exogenous surfactant treatment has been shown to ameliorate the lung injury in various animal models of the adult respiratory distress syndrome induced by saline lung lavage, ${ }^{45}$ injection of anti-lung serum, ${ }^{46}$ vagotomy, ${ }^{47}$ and prolonged hyperoxia. ${ }^{33}$ Prophylactic administration of surfactant considerably delays hyperoxic lung injury. ${ }^{48}$ Thus the idea that exogenous surfactant treatment could be beneficial in the adult respiratory distress syndrome is supported by the available in vitro and in vivo experimental work.

\section{Clinical studies of the adult respiratory distress syndrome} Case reports of exogenous surfactant treatment in the adult respiratory distress syndrome are limited. Three adults given a single dose of $4 \mathrm{~g}$ (about $50 \mathrm{mg} / \mathrm{kg}$ ) of porcine surfactant (Curosurf) showed a transient increase in arterial oxygen tension. The surfactant was instilled in divided doses with a bronchoscope. To sustain the improvement the authors suggested that repeated instillations would be required. ${ }^{49} 50$ Lachmann's reports of eight patients suggest that a dose of $200-300 \mathrm{mg} / \mathrm{kg}$ is required to achieve useful improvements in gas exchange. ${ }^{51}$ The patients studied so far have had severe adult respiratory distress syndrome; possibly administration earlier in the course of the disease and perhaps prophylaxis for those in high risk groups for developing the adult respiratory distress syndrome will be a more rational approach.

\section{Delivery of exogenous surfactant}

A major practical problem in the adult respiratory distress syndrome is the delivery of adequate amounts of surface active material to the alveolar air-liquid interface. In the premature neonate simple pharyngeal deposition of surfactant before the first breath may be sufficient because the air-liquid interface is at the mouth and the lungs are full of fluid at birth. ${ }^{52} \mathrm{~W}$ ith the first breath the interface rapidly spreads distally and carries the surfactant to all alveoli. In most recent studies, however, the baby is electively intubated and a fine catheter is used to instil the surfactant suspension in divided doses into four quadrants, with the baby positioned on its right/left side and head up/head down. Widely varying dosage regimens have been given to neonates. Doses of $100-200 \mathrm{mg} / \mathrm{kg}$ of surface active lipid suspended in 2-4 $\mathrm{ml}$ of saline have been used in most recent studies. ${ }^{17}$ This dose is based on the best estimate of the size of the alveolar pool of surfactant. ${ }^{21}$ Single and repeated doses have been used but the optimal regimen has not yet been determined.

In the adult repiratory distress syndrome the lungs are also "fluid filled" but delivery of surface active material to where it is needed most is made difficult by the large absolute distances in the adult lung. Injured lung units are closed, thus barring entry to the exogenous material. Nebulisation is a possibility but the mass of drug reaching the alveoli is small with this technique and the process of nebulisation may damage the surface activity of the preparation. ${ }^{53}$ Selective endobronchial instillation under direct vision with the fibreoptic bronchoscope is feasible and effective. ${ }^{51}$ Scaling up the neonatal dose to adult patients would mean $5-10 \mathrm{~g}$ of material in $100-400 \mathrm{ml}$ of suspension, and repeated doses may be required. The optimum regimen is unknown at present.

The problems of delivery have led some workers to study ways of stimulating the type 2 pneumocytes to synthesise and release more endogenous surfactant.

\section{Methods of increasing endogenous surfactant production}

In perinatal practice this approach has been used in mothers at risk of premature delivery. The rationale for the use of prenatal lung maturational agents is that, in the experimental context, corticosteroids alter lung structure, accelerate alveorisation, and stimulate the synthesis and secretion of surfactant by the fetal lung. ${ }^{21} 54$ In a national collaborative trial of the use of maternal corticosteroids to prevent respiratory distress syndrome there was a modest decrease in the incidence of respiratory distress syndrome-and also a lower incidence of patent ductus arteriosus and necrotising enterocolitis and more normal serum electrolytes, suggesting improved renal function. ${ }^{55}$ Interestingly, the combined use of prenatal corticosteroids and postnatal exogenous surfactant showed synergism in animal models. ${ }^{56}$

Type 2 pneumocytes have beta adrenoceptors on their surface $^{54}$ and prenatal use of beta 2 agonists, such as ritodrine or salbutamol, is an established treatment for 
suppression of premature labour. Beta agonists stimulate surfactant synthesis and secretion, so their use in this group of patients may have beneficial effects on the fetal lung. Thyroid hormones, oestrogens, prolactin, and muscarinic agonists also stimulate the surfactant cycle. ${ }^{54}$ Animal studies of thyrotrophin releasing hormone plus corticosteroids plus surfactant showed additive effects on lung function. ${ }^{56}$

Lung inflation promotes surfactant secretion by unknown mechanisms. ${ }^{54}$ This may have implications for the optimal mode of ventilation. High frequency oscillation of the surfactant deficient adult rabbit lung prevented the development of hyaline membranes and respiratory failure, whereas conventional ventilation severely damaged these lungs. ${ }^{57}$ In contrast, no benefit of high frequency oscillation over conventional ventilation could be seen in preterm lambs or rabbits or in a national collaborative clinical trial. ${ }^{21}$

Recently the mucolytic agent bromhexine (ambroxol) was shown to stimulate surfactant synthesis and release. ${ }^{58}$ It was effective in preventing and treating hyaline membrane disease in a double blind study of very low birth weight neonates. ${ }^{5960}$ Substantial improvements in gas exchange, mean airway pressure, lung mechanics, and the phospholipid profile of tracheal effluent were found. The incidence of bronchopulmonary dysplasia, intraventricular haemorrhage, and postnatally acquired pneumonia was also significantly reduced. The reduction of secretion viscosity and anti-stick properties may be additional advantages of this type of treatment in the adult respiratory distress syndrome, where the alveoli and small airways are full of proteinaceous exudate. Interestingly, the artificial surfactant preparation Exosurf (Wellcome) contains tyloxapol, which is also a mucolytic agent. A problem with this approach in the adult respiratory distress syndrome, however, could be that in injured areas of lung the type 2 pneumocytes are damaged early and the response to secretagogues may be grossly impaired.

The influence of nutrition on surfactant synthesis may be important. Inositol is an important nutrient in preterm infants and is known to potentiate the effect of corticosteroids on surfactant phospholipid synthesis. In a double blind clinical trial inositol treated infants had significantly increased concentrations of saturated phosphatidylcholine in tracheal aspirates, a lower incidence of bronchopulmonary dysplasia, lower mortality, and no retinopathy. The workers recommend the use of inositol in these infants because it promotes cell growth and glucocorticoid mediated type 2 cell differentiation and because it has antioxidant properties. ${ }^{61}$ An animal study of the effects of including fat in a total parenteral nutrition regimen ${ }^{62}$ showed an increase in saturated phosphatidylcholine, lung compliance, and total lung capacity in the fat treated group. The surface tension properties of lung lavage fluid were also improved in the fat treated group.

\section{Conclusions}

Surfactant preparations will soon be available commercially for preventing and treating neonatal respiratory distress syndrome. With the current knowledge of surfactant physiology and the pathophysiology of the adult respiratory distress syndrome perhaps exogenous surfactant treatment or stimulation of endogenous surfactant synthesis and secretion will prove to be beneficial in preventing and treating the adult respiratory distress syndrome. In addition to surface activity surfactant has cytoprotective actions, stimulates phagocytosis, enchances clearance of foreign particles, enhances clearance of alveolar fluid, reduces the permeability of the alveolarcapillary membrane, and overcomes the glue like proper- ties of exuded alveolar proteins. It is not clear which is the best surfactant preparation. The recent elucidation of the regulatory role of surfactant specific apoproteins suggests that those preparations nearest in composition to the natural material may prove to be superior. The apoproteins can be produced in the laboratory and a "genetically engineered" human surfactant for therapeutic use-a tantalising prospect-is surely just around the corner. Though anecdotal evidence of benefit in patients with adult respiratory distress syndrome exists, the laboratory evidence is not consistent. ${ }^{14}$ As soon as surfactant preparations become more widely available, trials should begin to define the role of surfactant treatment in the adult respiratory distress syndrome as an adjunct to available treatment techniques $^{6364}$ in a disease that still carries a very high morbidity and mortality.

Department of Anaesthesia,

N S MORTON

Royal Hospital for Sick Children,

Glasgow G3 $8 S J$

Reprint requests to Dr Morton.

1 Von Neergaard $\mathrm{K}$. New notions on a fundamental principle of respiratory mechanisms. The retractile force of the lungs, dependent on the surface tension in the alveoli (translated by Arnold R, Hahn H). In: Comroe JH, ed. Pulmonary and respiratory physiology. Part 1. Stroudsburg: Dowden, Hutchison, and Ross, 1976:214-34.

2 Lachmann B, Van Golde LMG, eds. 60 years of surfactant research. Proceedings of congress. Rotterdam: Erasmus University, 1989.

3 Comroe JH. Retrospectroscope: premature science and immature lungs. Part I. Some premature discoveries. Am Rev Resp Dis 1977;116:127-35.

4 Comroe JH. Retrospectroscope: premature science and immature lungs. Par II. Chemical warfare and the newly born. Am Rev Respir $D i$ 1977;116:311-23.

5 Comroe JH. Retrospectroscope: premature science and immature lungs. Par III. The attack on immature lungs. Am Rev Respir Dis 1977;116:497-518.

6 Clements JA. Dependence of pressure-volume characteristics of lungs or intrinsic surface active material. Am J Physiol 1956;187:592.

7 Clements JA, Brown ES, Johnson RP. Pulmonary surface tension and th mucus lining of the lungs: some theoretical considerations. J Appl Physio. 1958;12:262-8.

8 Avery ME, Mead J. Surface properties in relation to atelectasis and hyalin membrane disease. Am J Dis Child 1959;97:517-23.

9 Enhorning G, Robertson B. Lung expansion in the premature rabbit fetus after tracheal deposition of surfactant. Pediatrics 1972;50:58-66.

10 Ashbaugh DG, Bigelow DB, Petty TL, Levine BE. Acute respiratory distress in adults. Lancet 1967;ii:319-23.

11 Petty TL, Ashbaugh DG. The adult respiratory distress syndrome: clinica features, factors influencing prognosis and principles of management. Chest 1971;60:233-9.

12 Evans TW. Adult respiratory distress syndrome. Med Int 1989;71:2944-7.

13 Petty TL, Silvers GW, Paul GW, Stanford RE. Abnormalities in lung elastic properties and surfactant function in adult respiratory distress syndrome. Chest 1979;75:571-4.

14 Holm BA, Matalon S. Role of pulmonary surfactant in the development and treatment of adult respiratory distress syndrome. Anesth Analg 1989;69:805-18.

15 Fein AM, Goldberg SK, Lippmann ML, Fischer R, Morgan L. Adult respiratory distress syndrome. Br J Anaesth 1982;54:723-36.

16 Dobbs LG, Wright JR, Hawgood S, Gonzalez R, Venstrom K, Nellenbogen $\mathrm{J}$. Pulmonary surfactant and its components inhibit secretion of phosphatidylcholine from cultured rat alveolar type II cells. Proc Natl Acad Sci US A 1987;84:1010-4.

17 Morton NS. Pulmonary surfactant: physiology, pharmacology and clinical uses. Br J Hosp Med 1989;42:52-8.

18 White DT, Damm D, Miller J. Isolation and characterization of the human pulmonary surfactant apoprotein gene. Nature (Lond) 1985;317:361-3.

19 Floros J, Phelps DS, Taeusch HW. Biosynthesis and in vitro translation of the major surfactant-associated protein from human lung. $J$ Biol Chem 1985;260:495-500.

20 Hawgood S, Benson BJ, Hamilton RL. Effects of a surfactant-associated protein and calcium ions on the structure and surface activity of lung surfactant lipids. Biochemistry 1985;24:184-90.

21 Jobe A, Ikegami $M$. Surfactant for the treatment of respiratory distress syndrome. Am Rev Respir Dis 1987;136:1256-75.

22 Halliday HL, McCord FB, McClure BG, Reid MMcC. Acute effects of instillation of surfactant in severe respiratory distress syndrome. Arch Dis Child 1989;64:13-6.

23 Halliday HL. Treatment of respiratory distress syndrome with surfactant. Intens Ther Clin Monitoring 1990;11:75-9.

24 Seeger W, Stohr G, Wolf HRD. Alterations of surfactant function due to protein leakage: special interaction with fibrin monomer. J Appl Physiol 1985;58:326-8.

25 Fuchimukai T, Fukiwara T, Takahashi A, Enhorning G. Artificial pulmonary surfactant inhibited by proteins. J Appl Physiol 1987;62:429-37.

26 Holm BA, Notter RH. Effects of hemoglobin and cell membrane lipids on pulmonary surfactant activity. $J$ Appl Physiol 1987;63:1434-42.

27 Holm BA, Notter RH, Siegle J, Matalon S. Pulmonary physiological and 
surfactant changes during injury and recovery from hyperoxia. $J$ Appl Physiol 1985;59:1402-9.

28 Witschi HR, Haschek WM, Klein-Szanto AJP, Hakkinen PJ. Potentiation of diffuse lung damage by oxygen: determining variables. Am Rev Respir Dis 1981;123:98-103

29 Holm BA, Baker RR, Matalon S. Effect of reactive oxygen metabolites on type 2 cell surfactant synthesis. In: Lachmann B, Van Golde LMG, eds. 60 years of surfactant research. Proceedings of congress. Rotterdam: Erasmus University, 1989.

30 Holm BA, Matalon S, Finkelstein JN, Notter RH. Type II pneumocyte changes during hyperoxic lung injury and recovery. J Appl Physiol $1988 ; 65: 2672-8$

31 Matalon S, Holm BA, Baker RR, Freeman BA. Antioxidant properties of surfactant replacement mixtures. Am Rev Respir Dis 1988;137(suppl):80.

32 Walther FJ, Wade AB, Taeusch HW. Superoxide dismutase and catalase activity of lung surfactant preparations. In: Lachmann B, Van Golde LMG, eds. 60 years of surfactant research. Proceedings of congress. Rotterdam: Erasmus University, 1989.

33 Matalon S, Holm BA, Notter RH. Mitigation of pulmonary hyperoxic injury by administration of exogenous surfactant. $J$ Appl Physiol 1987;62:756-61.

34 Van Golde LMG, Van Iwaarden JF, Batenburg JJ, Verhoef J. Metabolic aspects of surfactant lipids and proteins. In: Lachmann B, Van Golde LMG, eds. 60 years of surfactant research. Proceedings of congress. Rotterdam: Erasmus University, 1989

35 Van Iwaarden JF, Ebscomp M, Van Strijp JAG, Verhoef J, Van Golde LMG. Surfactant protein A is an important mediator of phagocytosis of viruses by rat alveolar macrophages. In: Lachmann B, Van Golde LMG, eds. 60 years of surfactant research. Proceedings of congress. Rotterdam: Erasmus University, 1989.

36 Hein T, Lachmann B, Armbruster S. Pulmonary surfactant inhibits the cardiovascular effects of platelet-activating factor (PAF), 5-hydroxytryptamine (5-HT) and angiotensin II [abstract]. Am Rev Respir Dis 1987;135:A506.

37 Hills BA. Bursting the alveolar bubble. Anaesthesia 1987;42:467-9.

38 Hills BA. The biology of surfactant. Cambridge: Cambridge University Press, 1988:184-235.

39 Van Golde LMG, Batenburg JJ, Robertson B. The pulmonary surfactant system: biochemical aspects and functional significance. Physiol Rev 1988;68:374-455.

40 Evander E, Wollmer P, Johnson B, Lachmann B. Pulmonary clearance of inhaled ${ }^{99 \mathrm{~m}} \mathrm{TcDPTA}$ : effects of surfactant depletion by lung lavage. $J A p p l$ Physiol 1987;62:1611-4.

41 Barrowcliffe MP, Otto C, Jones JG. Pulmonary clearance of ${ }^{99 \mathrm{~m}} \mathrm{TcDPTA}$ : influence of background activity. J Appl Physiol 1988;64:1045-9.

42 Jones JG, Somerville ID. Lung surfactant: composition, physiology and replacement therapy. In: Kaufmann L, ed. Anaesthesia Review 6. Edinburgh: Churchill Livingstone, 1989.

43 Mason R. Surfactant in adult respiratory distress syndrome. Eur J Respir Dis 1987;71(suppl 153):229-36.

44 Holm BA, Enhorning GE, Notter RH. A biophysical mechanism by which plasma proteins inhibit surfactant activity. Chemistry and Physics of Lipids 1988;49:49-55.

45 Lachmann B, Robertson B, Vogel J. In vivo lung lavage as an experimental model of the respiratory distress syndrome. Acta Anaesthesiol Scand 1980;26:231-6.
46 Lachmann B, Hallman M, Bergmann KC. Respiratory failure following anti-lung serum: study on mechanisms associated with surfactant system damage. Exp Lung Res 1987;12:163-80.

47 Berry D, Ikegami M, Jobe A. Respiratory distress and surfactant inhibition following vagotomy in rabbits. J Appl Physiol 1986;61:1741-8.

48 Loewen GM, Holm BA, Milanowski I, Wild LM, Matalon S. Alveolar hyperoxic injury in rabbit receiving exogenous surfactant. J Appl Physiol 1988;66:1087-92.

49 Richmann PS, Spragg RG, Merritt TA, Robertson B, Curstedt T. Administration of porcine lung surfactant to humans with ARDS: initial experience [abstract]. Am Rev Respir Dis 1987;135(suppl):A5.

50 Richmann PS, Spragg RG, Merritt TA, Curstedt T. The adult respiratory distress syndrome: first trials with surfactant replacement. Eur Respir $J$ 1989;2(suppl):109-11.

51 Lachmann B. Animal models and clinical pilot studies of surfactant replacement in adult respiratory distress syndrome. Eur Respir $J$ 1989;2(suppl):98-103.

52 Enhorning G, Grossman G, Robertson B. Pharyngeal deposition of surfactant in the premature rabbit foetus. Biology of the Neonate 1973;107:921-7.

53 Marks LB, Notter RH, Oberdorster G, McBride JT. Ultrasonic and jet aerosolization of phospholipids and the effects on surface activity. Pediatr Res 1983;17:742-7.

54 Hollingsworth M, Gilfillan AM. The pharmacology of lung surfactant secretion. Pharmacol Rev 1984;36:69-90.

55 Collaborative Group on Antenatal Steroid Therapy. Effect of antenatal dexamethasone administration. In: Prevention of respiratory distress syndrome. Bethesda: National Institutes of Health, 1985. (NIH publication No 85-2695.)

56 Ikegami M, Jobe A, Pettenazzo A, Seidner SR, Berry DD, Ruffini L. Effect of maternal treatment with corticosteroids, T3, TRH and their combinations on lung function of ventilated preterm rabbits with and without surfactant treatments. Am Rev Respir Dis 1987;136:892-8.

57 Hamilton P, Onayemi A, Gillen J, Cutz E, Froese A, Bryan AC. Comparison of conventional and high frequency ventilation: oxygenation and lung pathology. J Appl Physiol 1983;55:131-8.

58 Disse BG. The pharmacology of ambroxol-review and new results. Eur $J$ Respir Dis 1987;71:(suppl 153):255-62.

59 Wauer RR. Ambroxol for prevention and treatment of hyaline membrane disease. Eur Respir J 1989;2(suppl):57-65.

60 Wauer RR, Schmalisch G, Bohme B, Arand J. Ambroxol therapy of hyaline membrane disease-results of a multicentre double-blind study in very low birth weight infants. In: Lachmann B, Van Golde LMG, eds. 60 years of surfactant research. Proceedings of congress. Rotterdam: Erasmus University, 1989

61 Hallman M, Bry K, Pohjavouri M. Inositol supplementation in respiratory distress syndrome. In: Lachmann B, Van Golde LMG, eds. 60 years of surfactant research. Proceedings of congress. Rotterdam: Erasmus University, 1989.

62 Bahrami S, Strohmaier W, Redl H, Schlag G. Mechanical properties of the lungs of posttraumatic rats are improved by including fat in total parenteral nutrition. J Parenteral and Enteral Nutrition 1987;11:560-5.

63 Hunter DN, Keogh BF, Morgan CJ, Evans TW. The management of adult respiratory distress syndrome. $1-B r J$ Hosp Med 1989;42:468-71.

64 Keogh BF, Hunter DN, Morgan CJ, Evans TW. The management of adult respiratory distress syndrome. 2-BrJ Hosp Med 1990;43:26-34. 